\section{Outcome of intussusception among children in Kano}

Lawal B. Abdullahi, ${ }^{1}$ Mohammad A. Mohammad, ${ }^{1}$ Lofty-John C. Anyanwu, ${ }^{1}$ Mohammad S. Aliyu, ${ }^{2}$ Bilya I. Liman ${ }^{2}$

${ }^{1}$ Surgery Department, Bayero University Kano/Aminu Kano Teaching Hospital, Kano; ${ }^{2}$ Pediatric Surgery Unit, Surgery Department, Aminu Kano Teaching Hospital, Kano, Nigeria

\section{Abstract}

Intussusception is defined as the telescoping of a segment of the gastrointestinal tract within the lumen of the adjacent segment usually proximal to distal. It is a common cause of intestinal obstruction in children, rarely it can occur in adult. This condition is reported in both developed and developing countries, however there are few publications in Nigeria about the incidence, presentation and outcome of its management, most especially in children. This is a prospective study of pediatric patients managed in single center Kano over a period of 18 months. The demographic data, clinical features, treatment and outcome of the management were evaluated and analyzed using SPSS version 23. Between June 2018 to December 2019, twenty-five children were managed with intussuception at Aminu Kano Teaching Hospital, there were 16 males and 9 females. The age of the patients ranges between 5 months to 6 years with most of patients in the ager range between 6 and 12 months. All of the 25 patients had exploratory laparotomy with manual reduction in 12 patients, while 13 patients had resection and anastomosis. Non-operative reduction using normal saline under ultrasound guidance was attempted for 2 patients, which was not successful. The length of hospital stay ranged between 4 days and 22 days. Few complications were observed which includes surgical site infection, wound dehiscence, postoperative ileus. One patient was re-operated for recurrent intussuception. Two patients died post operatively, while 23 patients were discharged home alive. Intussuception is still a common cause of intestinal obstruction in children in Kano. Late presentation was found to be associated with higher morbidity (complications).

\section{Introduction}

Intussusception is defined as the tele- scoping of a segment of the gastrointestinal tract within the lumen of the adjacent segment usually proximal to distal. It is first reported by Barbette of Amsterdam in 1674. ${ }^{1,2}$ It causes an occlusive-strangulation type of intestinal obstruction.

The incidence is estimated to be approximately 2-4 cases per 1,000 children, with a male to-female ratio ranging from $1.4: 1$ to $3: 2$. Intussusception is known to occur among children in Africa, but unfortunately its true incidence is not fully documented. ${ }^{3}$ It is reported to be more common in males than females and this is more remarkable during infancy. No pediatric age group is exempted from having intussusception, but it is more common in infants and toddlers. It is common between 3 months and 3 years of age, with peak age of 6 month to 9 months. Intussuception is classified as either primary (idiopathic) without a pathologic cause or secondary intussuception with a known cause. In pediatric age group primary intussuception is said to be more common. In the secondary intussuception there is a pathologic lead point in the gastrointestinal tract like Meckel's diverticulum, postoperative adhesions, lipoma, adenomatous polyps, lymphoma. ${ }^{4}$ In children the cause of intussuception is poorly understood however some risk factors are associated with intussuception. In this group of children, there may be hypertrophy of the mural lymphoid tissues, known as Peyer's patches, in the terminal ileum as a result of a viral illness (caused by adenovirus or rotavirus), with a history of acute gastroenteritis and/or respiratory tract symptoms. ${ }^{5}$

The clinical features of intussuception includes inconsolable cry of sudden onset, abdominal distension, vomiting, and passage of bloody mucoid stool. At presentation they are usually dehydrated, weak, anemic with distended abdomen. Digital rectal examination usually reveals empty rectum with scanty bloody mucoid stool. In our environment diagnosis of intussuception is still made late due to late presentation or sometimes a delay at the hospital, hence high index of suspicion is important for the diagnosis. The diagnostic investigation of choice is abdominal ultrasound, other investigation includes contrast enema, abdominal X-ray, abdominal CT, abdominal MRI and base line investigation likes full blood count, serum urea and electrolytes.

In children non-operative treatment with contrast enema is sufficient to reduce most of intussusceptions especially when they present early. When there is late presentation with severe abdominal distension, peritonitis or intestinal gangrene or in poor resources facility operative reduction is indicated.
Correspondence: Lawal Barau Abdullahi, Surgery Department, Aminu Kano Teaching Hospital, Zaria road Gyadi-Gyadi, tarauni local government, Kano, Nigeria.

E-mail: a.lawalbarau@yahoo.com

Key words: Intussusception; telescoping; proximal; distal.

Conflict of interest: The authors declare no conflict of interest.

Availability of data and materials: All data generated or analyzed during this study are included in this published article.

Ethics approval and consent to participate: The Ethics Committee of Aminu Kano Teaching Hospital approved this study (NHREC/28/01/2020/AKTH/EC/3166). The study is conformed to the Helsinki Declaration of 1964, as revised in 2013, concerning human and animal rights. All patients participating in this study signed a written informed consent form for participating in this study.

Informed consent: Written informed consent was obtained from a legally authorized representative(s) for anonymized patient information to be published in this article.

Received for publication: 24 August 2020

Revision received: 20 February 2021.

Accepted for publication: 20 February 2021.

This work is licensed under a Creative Commons Attribution NonCommercial 4.0 License (CC BY-NC 4.0).

(C) Copyright: the Author(s), 2021

Licensee PAGEPress, Italy

Pyramid Journal of Medicine 2021; 4:104

doi:10.4081/pjm.2021.104

\section{Materials and Methods}

This is a prospective study of pediatric patients managed in single center Kano over a period of 18 months. All the patients with intussusception managed in pediatrics surgery unit during this time were included in the study. The demographic data, clinical features, treatment and outcome of the management were evaluated and analyzed using SPSS version 23 .

\section{Results}

During the period of our study 25 patients were managed with intussuception in our unit, there were 16 males and 9 females, the age at presentation ranged 
between 5 months and 6years. Most of our patients presented after 48 hours of the onset of the symptoms. The most common symptoms are abdominal distension, vomiting, bloody stool and fever. Five patients presented with prolapsed intussuception through the anal canal (Figures 1 and 2, Table 1).

At presentation most of the patients were dehydrated with distended abdomen. Eight patients presented with anemia packed cell volume of less than $30 \%$, while $9(36 \%)$ of the patients has fever with temperature $>37.5^{\circ} \mathrm{C}$. Attempt at non operative reduction was done for two patients but was unsuccessful. All of the 25 patients had exploratory laparotomy with manual reduction in 12 patients while13 patients had resection and anastomosis was done in 13 patients. All of the patients who had resection and anastomosis presented 48 hours after the onset of the symptoms. Most of the patients did well post operatively.

Some complication observed post operatively includes surgical site infection in 4 patients, wound dehiscence in 2 patients, 3 patients developed post-operative paralytic ileus while 1 patients had re-operated for recurrent intussuception. Two patients died post operatively with mortality rate of about $5 \%$, while the remaining 18 patients were discharge home alive (Table 2)

\section{Discussion}

Intussusception is defined as the telescoping of a segment of the gastrointestinal tract within the lumen of the adjacent segment usually proximal to distal. 1 It is first reported by Barbette of Amsterdam in $1674 .^{2}$ Intussusception, especially the primary or idiopathic variety, is primarily a disease of childhood and is the commonest cause of intestinal obstruction between the ages of three months and two years. The incidence is said to be $2-4$ per 1000 children. 3,4

The etiology of intussusception in early childhood remains unknown, as the majority of intussusception has no definite etiological factor or demonstrable pathologic lead point unlike in older children and adults. ${ }^{6}$ Sometimes, intussusception occurs during the time of weaning and may have a seasonal pattern that coincides with attacks of viral upper respiratory tract infection or dry season. ${ }^{7,8}$ The common symptoms of intussuception are vomiting, abdominal distension, bloody stool, fever and anal anal protrusion. The commonest symptoms in our patients are abdominal distension in $56 \%$ of the cases, vomiting in $52 \%$, bloody
Table 1. Age distribution of the patients.

\begin{tabular}{lcc} 
S/ No & Age range (months) & 3 \\
1 & $0-6$ & 14 \\
2 & $7-12$ & 3 \\
3 & $13-18$ & 2 \\
4 & $19-24$ & 3 \\
\hline 5 & $>24$ & 25 \\
\hline
\end{tabular}

Table 2. Common presenting symptoms.

\begin{tabular}{lcc} 
S/ No & Symptoms & Number of patients (\%) \\
1 & Abdominal distension & $14(56)$ \\
2 & Vomiting & $13(52)$ \\
\hline 3 & Bloody stool & $16(64)$ \\
4 & Fever & $9(36)$ \\
\hline & Anal protrusion (prolapse) & $4(16)$ \\
\hline
\end{tabular}

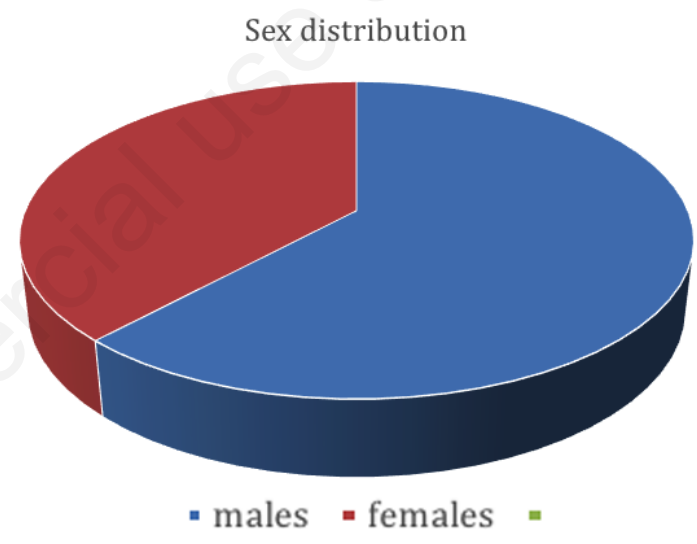

Figure 1. Sex distribution of the patients.

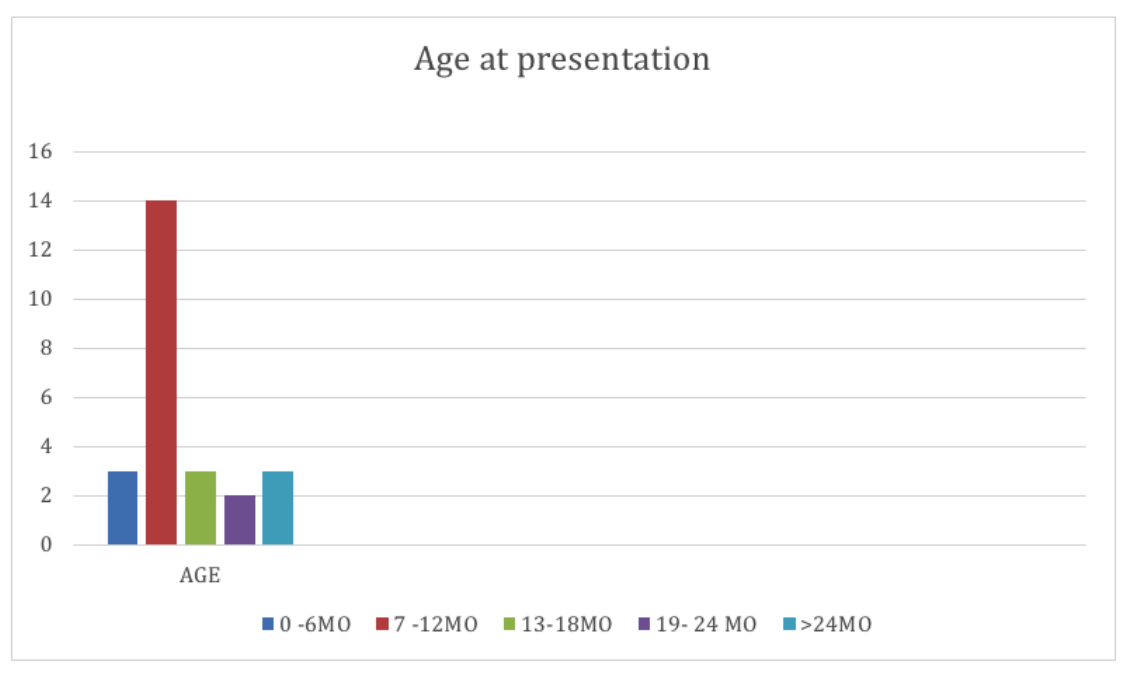

Figure 2. Age at presentation. 
stool in $64 \%$. This is similar to some studies in both North and southern part of Nigeria. ${ }^{9,10}$ Four (4) patients presented with prolapsed intestine through the anal canal. At presentation 15 patients $(60 \%)$ were dehydrated while 9 patients $(35 \%)$ had anemia, this is similar to a study by Ameh et al. who found that 5 of his patients had transanal protrusion of intussuception at presentation and most of the patients were dehydrated. ${ }^{11}$ After resuscitation with iv fluid, iv antibiotics, correction of anemia and electrolytes derangement, all of our patients had laparotomy, however non operative treatment was tried in 2 patients which failed. This is contrary to a study done by Buettcher, who was able to reduce $74 \%$ of his patients by non-operative treatment using enema method. ${ }^{12}$

At laparotomy 13 patients had resection of the affected bowel with end to end anastomosis while manual reduction was done in 12 patients. This was similar to finding in Zaria where 15 (45\%) out of 33 patients had resection and anastomosis but Archibong in Calaber reported that only $8(9 \%)$ of his 89 patients had resection while most of his patients had manual reduction. ${ }^{11,13,14}$

Some complications observed after the management are surgical site infection in 3 $(15 \%)$ of the patients, wound dehiscence in $2(10 \%)$ patients while 1 patient was reoperated for features of recurrent intussuception. These are similar to spectrum of complication reported by Chalya in Tanzania and Nuhu in Maiduguri. ${ }^{15,16,17}$

The outcome of our patients was good as only 2 patient ( $8 \%$ ) died before discharge while the remaining 23 patients were discharged home alive, with mortality of $8 \%$. This is contrary to findings by Venter in South Africa where all his 35 patients were discharge home alive with zero $(0 \%)$ mortality, but is similar to finding by Nmadu in Zaria where the mortality rate was found to be $8.6 \% .^{18,19}$

\section{Conclusions}

Intussuception is still a common cause of intestinal obstruction in children in Kano. Late presentation was found to be associated with higher morbidity (complications).

\section{References}

1. Egbuchulem KI, Lawal TA, Nweke MC, Adeoye AO. A case of compound intussusceptions in a Nigerian child - a rare finding in a common disease. Ann Ib Postgrad Med 2017;15:57-60.

2. Marinis A, Yiallourou A, Samanides L, et al. Intussusception of the bowel in adults: A review. World J Gastroenterol 2009;15:407-11.

3. Hesse AAJ, Abantanga FA, Lakhoo K. Intussusception. In Ameh EA, Bickler SW, Lakhoo K, et al. (eds). Paediatric Surgery: A Comprehensive Text for Africa. 1st edition. Global Help:404-11.

4. Talabi AO, Sowande OA, Etonyeaku CA, Adejuyigbe O. Childhood intussusception in Ile-ife: What has changed? Afr J Paediatr Surg 2013;10:239-42.

5. Tagbo BN, Mwenda J, Eke C, et al. Retrospective evaluation of intussusception in under-five children in Nigeria. World J Vaccines 2014;4:12332.

6. Ugwu BT, Mbah N, Dakum NK, et al. Adult intussusception: Jos experience. West Afr Med J 2001;78:213-16.

7. Mayellm J. Intussusception in Infancy and Childhood in Southern Africa. A Review of 223 Cases. Arch Dis Childhood 1972;47:20.

8. Bode CO. Presentation and management outcome of childhood intussuception in Lagos: A prospective study. Afr J Paeditr Surg 2008;5:24-8.

9. Ameh EA. The morbidity and mortality of right hemicolectomy for complicated intussusception in infants. Nigerian Postgraduate Med J 2002;9:123-24.

10. Ameh EA,Mshelbwala PM. Transanal protrusion of intussuception in infant is associated with high morbidity and mortality. Ann Trop Paediatr 2008;28: 287-92.

11. Buettcher M. Three-Year Surveillance of Intussusception in Children in Switzerland. Pediatrics 2007;120;47380.

12. Adejuyigbi O, Jeje EA, Owa ja.childhood intussuception in Ile-Ife, Nigeria. Ann Trop Paediatr 1991;11:123-7.

13. Archibong AE, Usoro IN, Ikpi E, Inyang A. Paediatric Intussusceptions in Calabar, Nigeria. East Afr Med J 2001;78:17-9.

14. Chalya PL, Kayange NM, Chandika B. Childhood intussusceptions at a tertiary care hospital in northwestern Tanzania: a diagnostic and therapeutic challenge in resource-limited setting. Ital J Pediatr 2014;40:2-8.

15. Nuhu A, Madziga AG. Childhood intussusception in north eastern Nigeria: a review of its surgical management. Port Harcourt Med J 2008;3:27-31.

16. Applegate KE. Intussusception in children: evidence-based diagnosis and treatment. Pediatr Radiol 2009;39:140 3.

17. Venter JA, le Grange SM, Joubert G. An audit of paediatric intussusception radiological reduction at the Bloemfontein Academic Hospital Complex, Free State, South Africa. S Afri J Child Health 2013;7:60-4.

18. Nmadu TP. The Changing Pattern of Infantile Intussusception in Northern Nigeria: A Report of 47 Cases. Ann Trop Paediatr 1992;12:347-50. 